\title{
META ANALYSES AND CONTROVERSY ABOUT FINANCIALIZATION, GROWTH AND STABILITY: A look from post-transition countries of last decade
}

Kristijan Ristic ${ }^{1}$

date of paper receipt:

20.04.2020.

Review Article date of sending to review:

23.04.2020.

doi: 10.2478/eoik-2020-0005 date of review receipt:

08.05.2020.

UDK: 338.22:339.564(4-664)

${ }^{1}$ Bussines and law faculty University Union - Nikola Tesla, Belgrade, Serbia

Keywords:

neoliberalism, growth, stability, doctrinal diversification 


\section{SOME OBSERVATIONS OF NEOLIBERALISM AND ITS CONSEQUENCES IN POST-PRANSITION COUNTRIES}

Neoliberal politics, hidden under the mask of monetarism, became rather influential as a new economic orthodoxy that regulated state politics, adopting the idea that Keynesianism should be rejected so that the economy of demand might be used with the purpose of ending the economic stagnation. Central banks and the IMF gradually dismissed the financial restrictions imposed on them as well as fiscal rules with the purpose of directing a new politics towards restricting inflation regardless of the consequential unemployment. Thus, a new era of a universal deregulation was started, dedicated to providing limitless market freedom of powerful corporate interests. Tax reliefs for new investments were increased for the capital to be directed to a higher percentage of profit. The institutional practice of deindustrialization and rearrangement of production facilities was applied worldwide despite the rise of unemployment, as its direct consequence.(Harvy, D., 2012) Deregulation performed in the field of banking, which created the speculative bubble in the distribution of loans in the real estate market, and the financial politics of the reduction of private and corporative taxes (that would stimulate investments) had turned into a mission adopted by the Central Bank to secure full employment which now became a struggle against inflation, i.e. the issue of macroeconomic stability.

Economic ideas fostered a neoliberal program based on the reduction of deficit, budget balancing and inflation control by means of international convergences while simultaneously avoiding the problems regarding employment and a fair share of income. Therefore, the neoliberal program became the cornerstone of the macroeconomic politics, which relied upon incremental autonomy, cachexia of small and medium-sized enterprises, altered conditions of capital debts, lobbying, bribe and participation in the election process. Yet, neoliberalism cannot subsist without a universal tendency towards an increase of social injustice and marginalization, hiding thus a harsh reality of a growing power of elite classes in the main financial centers of global capitalism.

An increase evident in the structural adaptation and the growth of the neoliberal reforms forced citizens to become an "addition" to the market. Advocating a reform of the global management with improved regulatory structures and a stricter supervision of financial activities, Stiglitz J. (2019a) and Krugman P. (2012) tackled the issues of income inequality and property ownership, which caused the structural crisis and degenerative structural reforms. A global economic recovery without an increase of the employment rate and with an income stagnation could be summarized as only a continuous rise of consumerism, exemplified in the American economy relying on enormous amounts of loans that support its squandering existence

Nowadays, most of the developed countries rely on the macro-prudential solvency - regulatory measures that include: control of the systematic financial risk, supervision of the financial market, reduction of the discrepancy between demand and supply, introduction of stricter standards for mortgage loans, restricted financing in purchasing real estates, increase of the level of countercyclical capital reserves necessary for the approval of housing loans, increase of mortgage payments, increase of the payment of mortgages, restricted use of pension funds when buying real estates. (Harvy, D., 2012)

Neoliberalism represents an economic and financial model whose essence is the creation of the conditions that will stimulate the mobility of the transaction capital and of the conditions necessary for the production and distribution that enable a more dynamic inclusion of certain countries into the global capitalism. The transnational capital uses its power (Stiglitz, J., 2019b) to undertake control over the state financial systems and thus additionally worsen the position of workers, increasing social inequality. The transnational capital uses its power to accelerate the process of decomposition of social state and social care system. 


\section{ECONOMIC POLICY OF POST-TRANSITION COUNTRIES UNDER THE AUSPICES OF THE CONTROVERSY OF ECONOMIC GROWTH AND FINANCIAL STABILITY: BETWEEN MYTH AND REALITY!}

In today's neoliberal capitalism, the highest value is the financial capital rather than human capital, which modern technological progress reduced to "nonsense". Today the employees as human capital, are treated as superfluous, since they are used and amortized. The fate of the majority of the over-fifty population is reflected in their replacement for the new model "trioxo olds" without the need to increase salary and to go to minimum retirement. We are destroyed by the robotization of production, which reduces the cost of the labor to one quarter, and that is why the unseen ease of removal from jobs is the new capitalist collective damage. (Ristić, K., Živković, A., Marjanović, N., 2018)

However, growth is not necessary for creation of new jobs, because it is always possible to produce more with the same amount of work. In that case, production profit does not depend on the job market. And a production growth lower than the production value contributes to diminishing volume of work and volume of jobs, under the condition that work hours stay the same. Further, the harmonization of production and consumption incorporates the quality of common social and economic goods into the center of human activity in order to avoid the problem of inequality. This, in turn, means that a sustainable economy, as a rule, starts from nature, labor, people and societies that resort to low technology without lack of innovation. (Greif, A., Iyigun, M., 2013).

Certainly in these constellations there is a new form of re-designing jobs. And this is different from the high technology of the current productivity economy, because for the same quantity of products, obviously more human labor should be needed to produce ecologically in standard working and living conditions. And this is achieved without an orientation to growth; and when economic growth occurs, not all macroeconomic policy goals are "diminished" in the full employment plan. That is why growth is a cult that is disappearing and that is why new ways of human progress must be explored. (Gregory, P., Stuart, R., 2015)

The current application of various financial salves to the wounds caused by the recession has led to a different use of fiscal rules: France and Italy have increased taxes, while Turkey, Spain and the United Kingdom have cut taxes give evidence. The Institute of Public Finances has announced that Italy and France have relied on tax increases in order to preserve debt, while Britain and Spain have resorted to austerity measures. However, the researchers criticized the intentions of responding to the economic crisis as they have missed the opportunity to improve the efficiency of their own accompanying systems in terms of financial stability, economic recovery, economic growth and global equity. In that context, Piketty T. (2014) with Paul Krugman (2012), pointed out that the global distribution of income is no longer the same as the distribution of production, since the countries with the highest production per capita tend to appropriate some of the capital of other countries and earn capital income from countries with low-production per capita. This is the reason for inequality of labor income, especially earnings, even though economists think that the logic of economic growth reduces the difference between work and capital. Thus Nobel Prize winner Stiglitz J. (2019c) is correct when he concludes that economics, as a science, has shifted from scientific discipline to mere cheering for the free market capitalism, more so than economic experts want to believe it.

Global inequality implies that wealth accumulated in the past increases faster than the pace of progress of production and earnings. And once the capital is created, it reproduces itself faster than production increases. So Piketty T. (2014) proposes to tax returns on capital sufficiently highly for private yield to fall below the rate of growth without compromising the incentives for accumulation. Progressive annual capital tax, in this context, allows avoiding the endless spiral of inequality while preserving competition and stimulating accumulation.

Central banks, due to the blind belief in financial stability, focused, as a rule, on inflation; now, tardily, they are also firmly focused on economic recovery and financial stability, but not on 
unemployment and growth; because expansive monetary policy (so-called quantitative easing) is more committed to financial stability than to macroeconomic stabilization.

Christine Lagarde, presenting the global economic plan for 2016, stressed the need for economic policy makers to support spending, financial stability, structural reforms, investment, new employment and infrastructure. In this context the latest IMF research has also shown that in advanced economies the increase in investment demand of one percentage point of GDP increases the average level of production by about $0.4 \%$ during the same year and $1.5 \%$ for four years after the increase in consumption.

In practice, there is already four proofs that economies achieve better results in certain labor markets and with lower inequality. Low salaries will not mean high profits, nor will low interest rates mean high bond prices. Therefore, the FED (Federal Reserve) was more skillful in achieving price stability, and much less successful in promoting full employment. But with the stagnation of wages, stronger dollar and inflation below the targeted two percent, only the high price of capital can be a support for healthy growth (even though banks are very reserved in terms of financing) and financial stability.

The increase in interest rates and the slowing down of the Chinese economy instigate the increased uncertainty and unpredictability of the economic issues of the free economy, accompanied by the downward path of world trade and the fall in oil prices. This, however, means that global financial stability is not ensured, as financial risks are already rising in emerging countries. Growth is restricted by low productivity, high debt, low level of innovation, weakening of banks, and an increasingly older population. The Chinese transition to the new model of growth and the "normalization" of US monetary policy contribute to this state of affairs. With a slight increase in the interest rate to $0.5 \%$ the Fed continues trying to lure investors, with low interest rates, to focus more actively focus on yields and take on financial risks in terms of growth in valuation of assets, government bonds and corporate loans. In this context, on the fiscal side, the IMF recommends increasing the space for fiscal stimulus, in order to encourage investment in the public sector and quality infrastructure. So-called credible mid-term fiscal programs remain a priority in the US and Japan. (Ristić, K, Živković, A., Marjanović, N.2018)

With almost the lowest tax rates, high tax deductions and robust subsidies, foreign companies' tax burdens in our country are 5-6\%, which means that the state budget looses about $0.5 \%$ of GDP annually. In the practice of advanced countries it turns out that the level of taxation is not a key element in making investment decisions, nor is it a key factor in increasing the competitiveness of the offer. (Ristić, K, Živković, A., Marjanović, N.2018)

That is why the initiated currency war, is first intensified in the import-export policy with open protectionist measures and hidden stimulus mechanisms, then moved from the real sector to the banking industry and the financing of new economies, mostly through a loan of "debts" and financial derivatives to "tear down" financial stability.

Deregulation contributed to the financialization of the economy; a poorly regulated financial sector closely related to inequality, allowing manipulation of the "rules of the game". Financialization has thus become a crucial factor in increasing the instability of the economy. But the unjust tax system reformed the economy, causing greater inequality after tax deductions, greater instability and degradation of growth. The unimaginably seamless global tax regime has led to the impoverishment of the public sector, so that "America is no longer a country of broad opportunities." Because, countries with a high degree of inequality invest in public goods, such as infrastructure, technology and education that contribute to long-term economic projects, financial stability.

In the modern history of digital economy, the Internet is increasingly viewed as a technological form of modern capitalism, "making profits at every step without the presence of a tax form." That is why David Cameron was forced to introduce a "redirected profit tax" at a rate of $25 \%$, while the French Minister of Culture tried to introduce tax on bandwidth (amount of transfer) of information in order to finance cultural excellence from that fund.

Innovative investment in education, world capital, research across the entire investment chain is a macroeconomic imperative whose penetration would raise the level of productivity and 
competitiveness. Today's public and corporate financing, however, is focused on short-term funding, which is exclusively focused on short-term goals. Only public financing does not "work" with speculative investment capital; and most of the existential business (private) financing is too speculative and only short-term. And this in fact means an over-focusing of the real sector on shortterm goals, by definition cause the design of a system of incentives to reinvest profit in production, development, research and innovation, as opposed to profits being "spent" for the purchase of own shares affect their price growth. Through this "egoistic nonsense", companies have made nearly four thousand billion dollars of profits; and therefore, long-term financing should include state-owned commercial banks and specialized government agencies, such as in America and China.(Stiglitz, J., 2019d)

In this sense, the public sector should take on key risks in the innovation chain, while strongly strengthening public institutions, as well as the capacity of public services. The public sector in partnership with the private sector would make the government more efficient. In that case, the government would change its "imprudent" approach to debt repayments.

Namely, instead of the current exclusive focus on budget deficits, the government would inevitably devote itself to the public debt ratio: GDP in terms of insufficient focus on a denominator called BPD and public investments that increase long-term productivity and infrastructure capacity. This, in turn, means effective investment in education, innovation, research, human capital, training and well-planned social programs, which contribute to economic adjustment, sustainable development and inclusiveness. Investment cohesion policy would incorporate the development of the green economy, and fiscal stimulus would also provide green development and transformation projects that are much higher than renewable energy sources. Monetary policy would still create an additional amount of money through quantitative easing, which would stimulate the green sector, instead of this money ending up in banks that do not give loans to the economy due to low interest rates.

Monetary policy thus ignores the economic code of the global economy that implies that cheap money goes into the real sector, i.e. production, and not securities, i.e. worthless papers and derivatives. Additionally, the dependence on austerity measures among the countries of the European Union and on the periphery of the eurozone contributed to the growing distrust of investors, and consequently the slowdown in economic activity and retroactively led to a "corruption" of growth as a myth or cult.

On the fiscal plane the OECD also turns over a new leaf: in 2015 a new deal was reached on new rules on profit taxation: companies will now be less able to transfer profits to low-tax and taxsafe ports, bringing an additional 250 billion dollars annually from tax revenues. The rules on the erosion of the principal and the transfer of profits are directed towards closing the legal loopholes and limiting the use of tax havens, in order to indirectly contribute to the fiscal wallet that creates the budget deficits. (Ristic, Zivkovic, Marjanovic, 2018c)

This is clearly the global target of increasing tax revenue, which is reflected in the process of increasing the share of direct taxation of the rich by applying higher progressive income tax, through a balanced ratio of direct and indirect taxation, through the organization of the taxation of dividends, interests, royalties and management fees, the reduction of losses in tax revenues due to globalization (capital movements increase the possibility of tax evasion due to limited capacity for the tax authority to check abroad the income of its citizens and due to the systemic concealment of relevant tax information from certain governments and financial institutions due to the diversity of tax regimes on the international plane, taxation and different treatment of income companies, due to increased concessions to foreign investors, due to the shifting of revenues from country to country by companies that strive to reduce tax liabilities). (Stiglitz, J., 2019e) 


\section{THE TOPICALITY OF FORMER DOCTRINAL CONFLICTS IN ECONOMICS. ARE POST-TRANSITION COUNTRIES “VICTIMS" OR ARE THERE STILL CHANCES?}

In the process of determining short-term changes in income, the Keynesians devote special attention to developments in certain economic sectors. Non-monetarist Keynesians explain the movement of income by considering expenditure incentives in each sector individually, because fluctuations can be initiated in different sectors only if the economic sector is unstable. An increase in interest rates, e.g. has various effects on housing construction, and consequently also on production if the mortgage lenders do not have sufficient liquid assets.

Keynesians usually claim that the capital market is imperfect and that in determining the total demand, knowledge of the total amount of liquid assets in all economic sectors is essential. When analysing the impact of monetary factors on nominal income, Keynesians are more likely to get to know all relevant information about interest rates and financial markets because they emphasize that the conditions for obtaining loans are the only channel of monetary policy activity. The Keynesians insist on rationalizing the capital (because of the imperfections of the capital market) and analysing cash flows much more than monetarists (although the latter place more relevance on the money). Therefore, in the Keynesian Federal Reserve - MIT - Penn model, lending limitation is one of the key channels of monetary policy's influence on income, because borrowing costs are the only channel of action, although there are several channels in the developed model. On the other hand, Keynesians place equal importance on phenomena in all sectors due to the necessity of state intervention in the economy and the belief in the fact that inflation can be a consequence of trends in certain sectors (such as sectoral and structural inflation) rather than a single general factor as monetarists consider. In the process of studying short-term changes in income, monetarists are not very interested in individual events (unless they are interested in criticizing state intervention in the financial market because they oppose limiting the interest rates on deposits held with banks). Monetarists unambiguously make the difference between the general price level (under the influence of the amount of money) and the relative prices (influenced by sector movements) and estimate the total expenditure on the basis of change in money supply. Because the increase in money supply must always have the same effect on total income regardless of the assumption of a fluid capital market. Only if the velocity of the money circulation varies by sector, monetarists are interested in analysing the distribution of money between sectors, but not in analysing the effects that the increase in money supply can have on the relative income of individual sectors.

This stems from the fact that monetarists believe in:

(1) the stability of the economic sector,

(2) unnecessary state intervention, and

(3) the lack of determination in establishing the impact channels of the monetary factors in different sectors. (Živković, A, Ristić, K., 2020)

The creators of large econometric models, as a rule, point to the correlation between macroeconomic trends and phenomena in individual sectors in the sense that aggregate fluctuations result from the cumulative effects of changes and disruptions in all individual sectors. In addition, the problem of impulses is usually used to prove the dependence of macroeconomic trends on individual sectoral processes. By contrast, the adherents of the smaller parts reject these eclectic stances, i.e. implicitly descriptivist conception and instrumental approach of Keynesians .

This monetarist stance stems from the dominant influence of the change in money supply on the nominal income, as the basic postulate of quantitative theory, the perception that specifics of certain sectors and the borrowing costs are a measure of influence of monetary factors. This, however, does not mean that monetarists, when forecasting fluctuations in income, cannot take into account individual phenomena; it also does not mean that they find that capital rationalization is necessary due to an unfinished capital market and that they do not frown upon state intervention due to nonbelief in the stability of the economic sector. (Živković, A, Ristić, K., 2020) 
Monetarists are opponents of state intervention and supporters of the free market process. The Keynesians, on the other hand, are supporters of the state intervention and opponents of adhoc market mechanism. As opponents of state intervention, monetarists do not think that a countercyclical fiscal policy should be pursued; because, as Mayer (Živković, A, Ristić, K., 2020) claims, a countercyclical fiscal policy can cause a higher increase in public sector spending in the recession period than a reduction in expenditures in the period of expansion and, therefore, public expenditures are continuously increasing. However, Tobin pointing to a negative attitude (Živković, A., Lakić, S., Ristić, K., 2019) argues that inflation cannot be used as a reason for budget cuts, if fiscal policy has little or no effect on income. The undesirability of countercyclical fiscal policy is a logical consequence of the monetarist understanding of the stability of the economic sector and the free market having better performance than state intervention in the national reproduction. The rule on a constant rate of monetary expansion excludes the need for the pursuit of discretionary policy, since the previously defined Philip's curve does not allow an optimal combination of inflation and unemployment. Therefore, the use of money supply (and not interest rates and bank loans), as a monetary policy objective, allows economic policy makers to concentrate on managing the variable (i.e. focus on the money supply) outside the domain of the market impact, on the one hand, and leave the determination of interest rates and bank loans to the free market, on the other hand. Finally, the monetarists are enormously worried about the multiple link between inflation and the expansion of the public sector, for three reasons: firstly, inflation increases public sector participation (and results in public spending increase) if the tax system is progressive; Secondly, suppressing inflation can only indirectly limit public sector expenditures, as government expenditures are partly increased by inflationary financing, and, thirdly, the financing of the budget deficit by primary emission generally involves an inflationary factor, which, if pursues can start the process of price control and wages.

If pure fiscalism is a school of thought according to which "money has no significance," then (1) the economic effects of fiscal measures are independent of the manner of financing and (2) the change in the amount of money without affecting the level and dynamics of economic activity (provided that fiscal measures do not imply either injecting fresh money in business flows, nor withdrawal of money from the economic sectors).

On the other hand, if pure monetarism is a school of thought according to which "only the money is important," then (1) the economic effects of a change in money supply are substantially independent of the manner in which the money is injected in or withdrawn from the economy and (2) negligible are the impacts of fiscal policy measures on the economy, if their monetary consequences are excluded . If one expansionary fiscal measure (expansion) is followed by monetary expansion in order to keep the interest rate growth and prevent the attenuation of the multiplier, some authors poses the following question: is the consequent increase in income the result of the IS curve movement or the LM curve movement, i.e. fiscal and monetary expansion? The answer certainly depends on the elasticity of its functions in relation to the interest rate. Inelastic IS and / or infinitely elastic LM gives fiscal responses, and infinitely elastic IS and / or inelastic LM gives monetarist responses. However, by keeping the rise in nominal interest rates, monetary policy needs to confirm the value of expansive fiscal policy. The definition of the budget, the nature of expenditure policies, the degree of tax revenue response, and the assumptions about the interchangeability between different types of assets all have influence on the creation of different theories.

Monetarists argue that favouring fiscal policy as an instrument of economic policy in easing the economic fluctuations is a mistake, but they do not claim that fiscal policy has no effect. Back in 1948 Friedman (Živković, A., Lakić, S., Ristić, K., 2019) once stressed the significance of the automatic effects of budgetary policy on short-term stabilization, as some fiscal measures (e.g. expenditures) can effectively serve in certain phases of the economic cycle, especially if we take into account the delayed effects of monetary policy. Friedman's in 1970 ((Živković, A., Lakić, S., Ristić, K., 2019) advocating the so-called non-discretionary fiscal policy is something else, which must not mean 
total denial of the potential of the assets of discretionary fiscal policy. Monetarists, therefore, only insist on changing the order of priorities in implementing monetary policy in relation to fiscal policy. On the other hand, monetarists are sceptical about the results of the applied fiscal policy that fiscalists often glorify. Changes in the level of public expenditures, which, as a rule, are delayed, due to the administrative timelags, and changes in tax rates on which fiscal stabilization is overly focused, are in practice at an uncertain level reproduced into expenditures and consumption. On the other hand, changes in tax rates (which governments often increase or decrease) cannot always be controlled due to their effects on income distribution. It is also not possible to control budget deficits due to the inability to firmly link changes in public expenditures and fiscal revenues, changes in fiscal and economic flows, and changes in non-inflationary financing of fiscal measures. As a result, monetarists consider that discretionary fiscal changes are not needed as an instrument of economic stabilization during the long-term application of stable monetary growth.(Živković, A., Ristić, K., 2020)

\section{CONCLUSION}

The financial sector of the global economy has imposed the idea that the market in itself leads to an efficient and stable outcome. Stressing that monetary policy must focus on inflation, not on job creation, including hard focus on fiscal deficits. And the deficit cannot always be a problem; not if the money is spent on investments and especially if this is done while the economy is weak. The current fundamental economic problem lies inside financial capitalism, which strives to surpass the famous industry sector in favor of financial market technology. Financial capitalism, as such, is a monopolistic one, creating bubbles instead of development. Economy, in this context, is based on financial speculation with illusions of endless growth, which is in contrast to the real sector. This is the path to abyss in the context of globalization, which insists on deregulation and liberalization and on structural reforms in post-transition countries. In modern economies, where GDP growth is determined by demand, and not by offering, austerity measures are wrong by definition because they reduce demand. Therefore, the global goals of the contemporary world are contradictory, they ignore economic recovery and employment, and force austerity and price stability. 


\section{REFERENCES}

Harvy, D. (2012) Kratka istorija neoliberalizma, Mediteran Publishing, Beograd Gregory, P. \& Stuart, R. (2015) Globalna ekonomija i njeni ekonomski sistemi, Ekonomski fakultet, Beograd.

Greif, A. \& Iyigun, M. (2013). Social organizations, violence, and modern growth. American Economic Review Papers and Proceedings.

Krugman, P. (2012) Okončajte ovu depresiju. Odmah!, Helix, Smederevo.

Piketi, T. (2014) Kapital u XXI veku. Akademska knjiga. Novi Sad.

Ristić, K. \& Živković, A. \& Marjanović, N. (2018). Kontroverze ekonomskog rasta i finansijske stabilnosti, Quantitative and qualitative analysis in economics, Faculty of economics, Universitet of Nis.

Stiglitz, J. (2019) Globalizacija i njene protivrečnosti - antiglobalizacija u Trampovoj eri, MibaBook. Beograd.

Stiglitz, J. (2019) People, Power, and Profits: Progressive Capitalism for an Age of Discontent, W.W. Norton, April 2019. Also published in the UK by Allen Lane/Penguin.

Stiglitz, J. (2019) After Neoliberalism: The Need for a New Paradigm, Speech during presentation of Honorary Doctorate, École Normale Supérieure de Lyon, Lyon, France, November 5, 2019.

Stiglitz, J. (2019) An Alternative Vision for the Global and European Economies, speech at the European Trade Union Confederation conference, Vienna, Austria, May 22, 2019.

Stiglitz, J. (2019) Structural Transformation, Deep Downturns, and Government Policy," The Oxford Handbook of Structural Transformation, Célestin Monga and Justin Yifu Lin (eds.), Oxford: Oxford University Press, pp. 35-44, March, 2019.

Živković, A. \& .Ristić,K. (2020). Analysis the functional domain of doctrinal approaches in monetary theory and policy. Ekonomika, Društvo ekonomista, Niš.

Živković, A. \& Lakić, S. \& Ristić, K. (2019). Monetarni menadžment, monography, Ekonomski fakultet, Beograd. 